\title{
STUDIES OF THE ANEMIA AND IRON METABOLISM IN CANCER ${ }^{1}$
}

\author{
By AARON MILLER, ${ }^{2}$ ROBERT B. CHODOS, ${ }^{3}$ CHARLES P. EMERSON, AND \\ JOSEPH F. ROSS 4 \\ (From the Robert Dawson Evans Memorial, Massachusetts Memorial Hospitals, and the Radio- \\ isotope Unit and Medical Service, Boston Veterans Administration Hospital, and \\ the Department of Medicine, Boston University School of Medicine, \\ Boston, Mass.)
}

(Submitted for publication May 29, 1956; accepted July 26, 1956)

Anemia is a common occurrence in patients with malignant neoplastic disease. It is often associated with chronic blood loss and occasionally with chronic infection. However, in the majority of instances, the anemia cannot be ascribed to these causes and no basis for its development is discovered other than the existence of cancer. It has been interpreted by some investigators as a reflection of toxic bone marrow depression or destruction of the marrow by tumor metastases. However, hemoglobin concentration and the size of the total erythron (1-3) may be normal in the presence of bone marrow metastases. Recently it has been proposed (4-6) that the anemia of cancer may occasionally result from a diminution in the life span of the red cell. Also, an increased rate of red cell destruction has been noted in leukemia and lymphoma (7). Hypoferremia in cancer in the absence of chronic blood loss has been described by many investigators (8-10). Usually, but not invariably, this has been associated with anemia. Its pathogenesis and its relationship to the anemia of cancer are alike obscure.

The purpose of this investigation has been to study the effect of cancer on iron metabolism and to delineate, if possible, the mechanisms responsible for anemia in patients with neoplastic diseases.

\section{METHODS}

\section{Clinical Material}

Thirty-eight patients with a diagnosis of carcinoma except for patients No. 17 and 20 were studied. Metastases were present in all but 4 of these patients (Tables

\footnotetext{
1 Work supported in part by AEC Contract "301" 919.

2 Formerly Post Doctorate U. S. Public Health Service Fellow at the National Cancer Institute.

8 Present address: Syracuse Veterans Administration Hospital, Syracuse, New York.

1 Present address: School of Medicine, University of California at Los Angeles.
}

I and II). Primary renal and liver disease, blood loss, overt hemolytic anemia, and infection were excluded by clinical examination and laboratory findings.

\section{Experimental Plan}

The subjects were hospitalized during the initial period of investigation, and subsequently when necessary. Fecal urobilinogen and radioiron studies were begun during the first week of hospitalization. A transfusion of labelled red cells for the purpose of measuring erythrocyte survival was begun after completion of the above studies. All phases of this program were completed in only 3 cases.

\section{Procedures}

\section{1) Hematological}

Erythrocyte count, hematocrit (11), and hemoglobin (12) were measured in all patients. Reticulocyte count by the aqueous cresyl-blue method, quantitative serum bilirubin (13) and Coombs test were done on most of the patients.

\section{2) Urobilinogen excretion and hemolytic indices}

Fecal urobilinogen was determined on four-day stool collections by the method of Schwartz, Sborov, and Watson (14) and the hemolytic index then calculated (15).

\section{3) Blood volume determinations}

The red blood cell volume was determined in 15 patients by the $\mathrm{P}^{\mathrm{s}}$ tagged red cells technique, and in the remaining patients, plasma volume was determined by the Evans blue dye method of Gibson and Evans (16). When the total red cell volume was calculated from the Evans blue determined plasma volume, the venous hematocrit was corrected by the factor of 0.92 (17).

\section{4) Erythrocyte survival studies}

(a) Ashby red cell survival studies. Thirteen individual red cell survival studies were performed in 12 patients. In patients No. 23,27 and $31, x$-ray treatment ranging from 2,000 to 8,000 $\mathrm{r}$ had been completed within a minimum of 16 days before survival studies began. Each patient was transfused with 500 or $1,000 \mathrm{cc}$. of normal donor blood, freshly collected in ACD, except in three cases, where the blood was from 3 to 6 days old. Inagglutinable counts were 20,000 or below per mm. in all but two cases. The differential agglutination tech- 


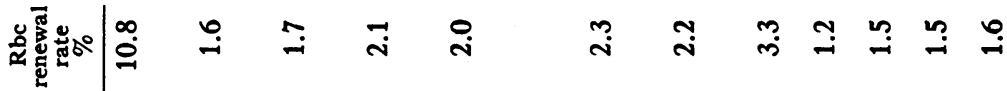

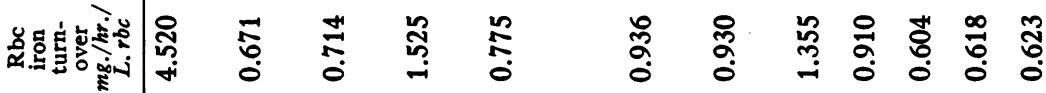

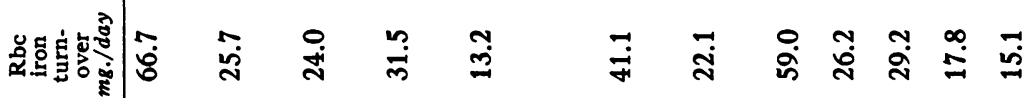

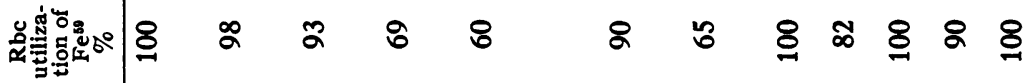

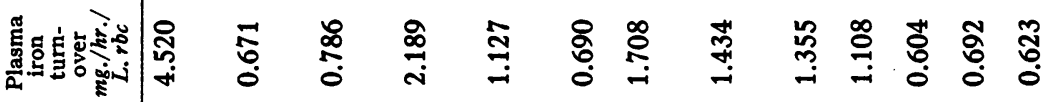

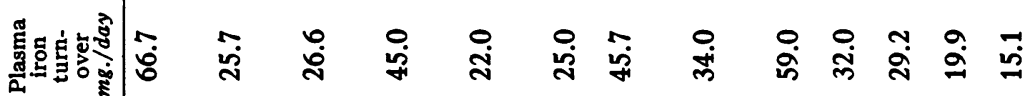

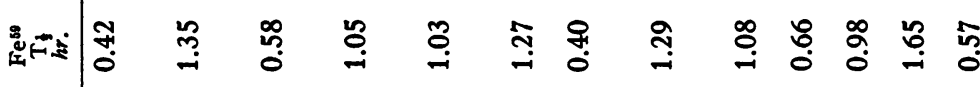

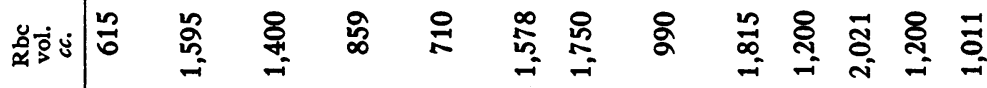

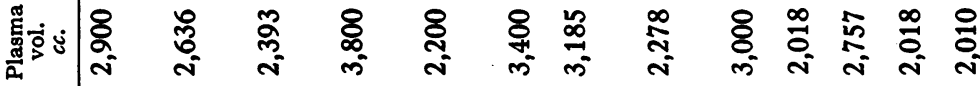

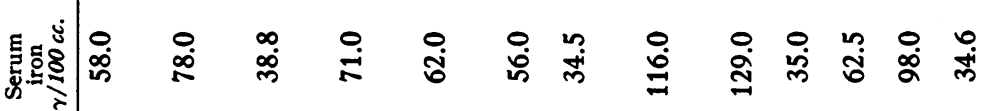

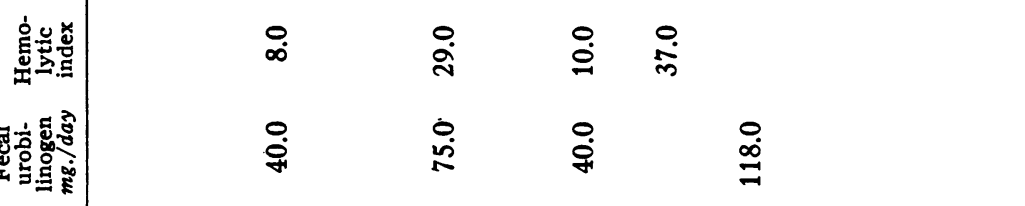

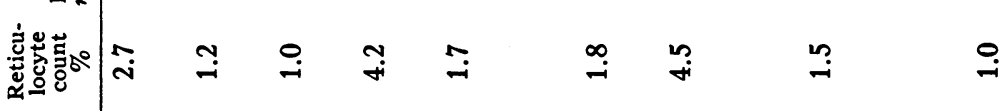

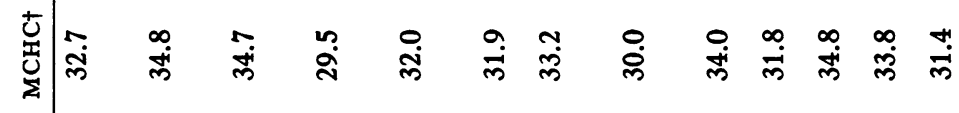

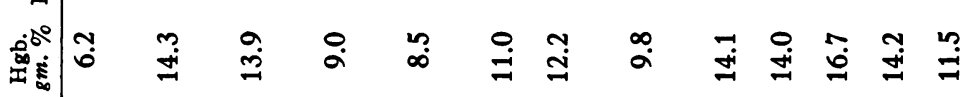

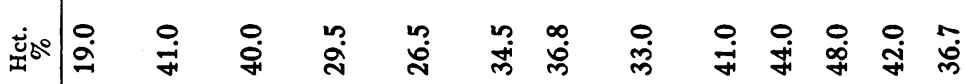

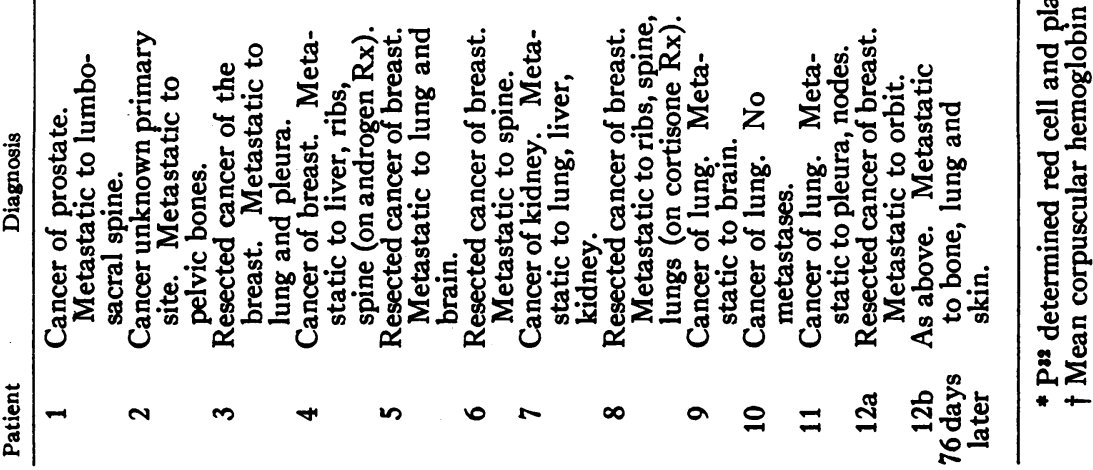




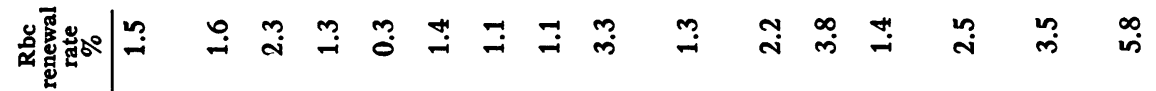

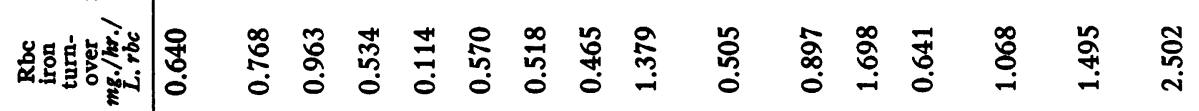

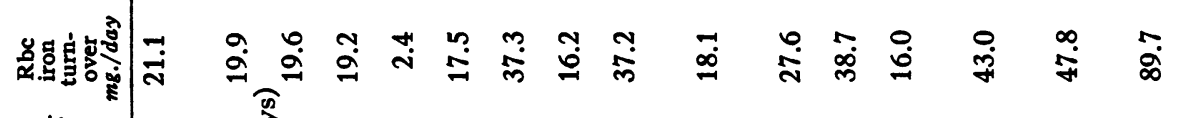

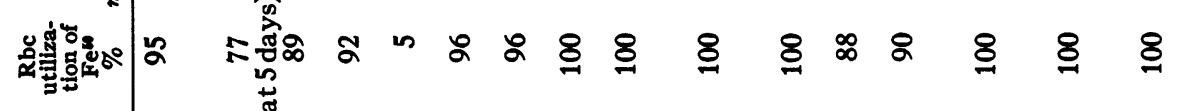

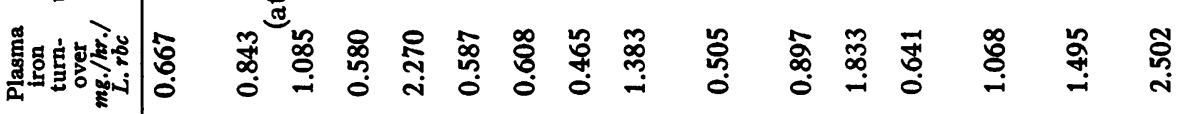

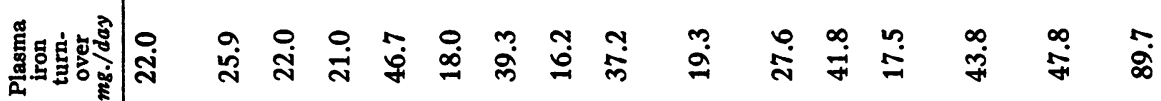
踏:

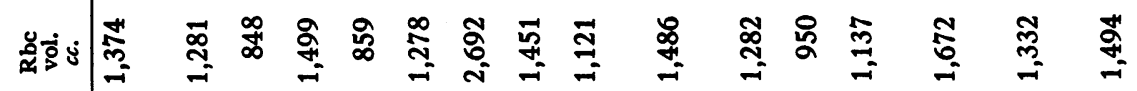

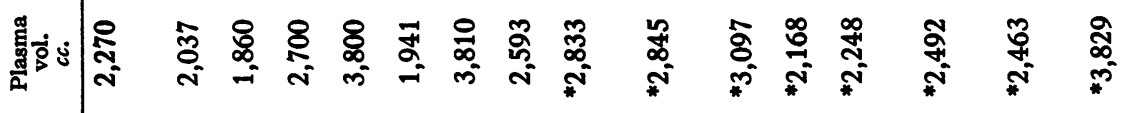

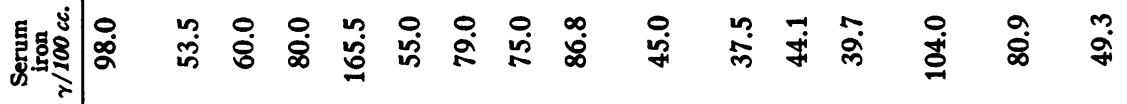

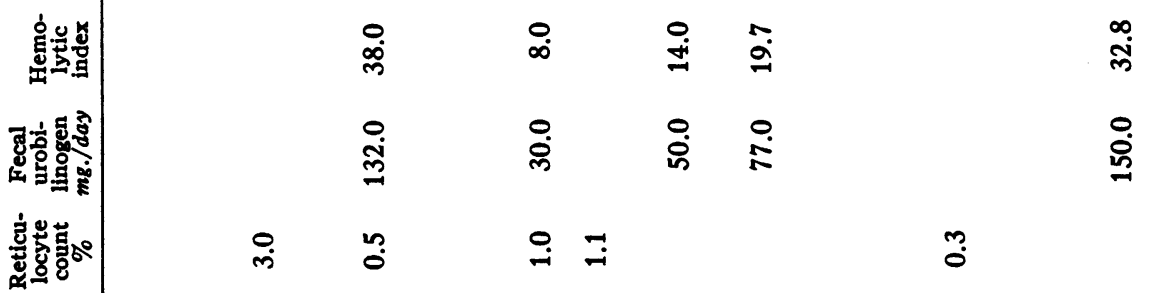

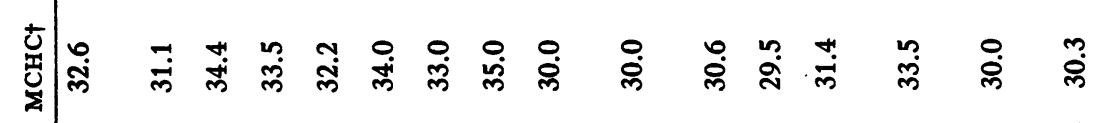

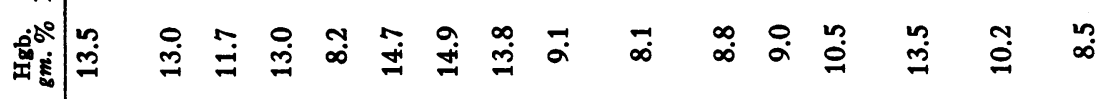

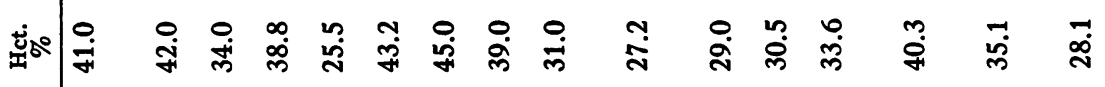

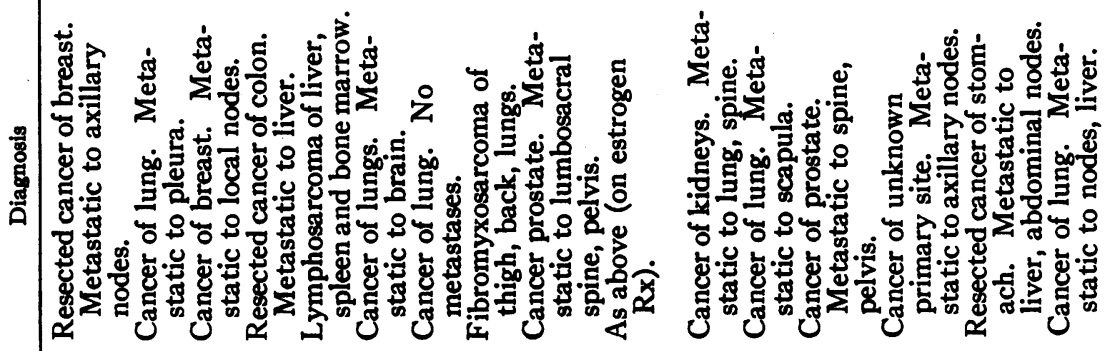
嵒 


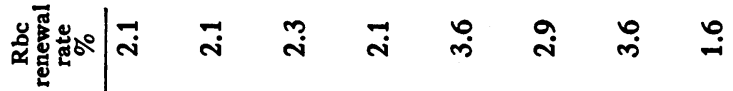

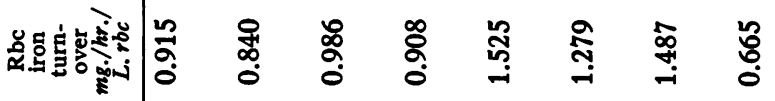

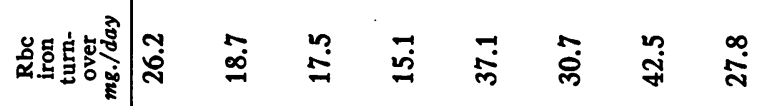

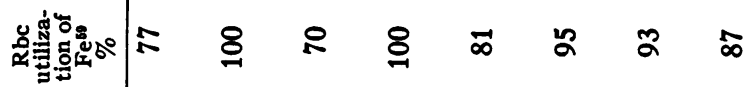

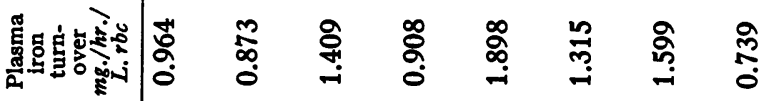

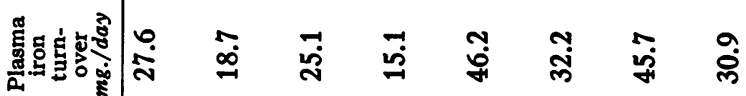

:

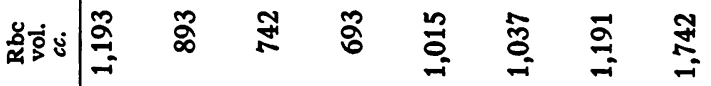

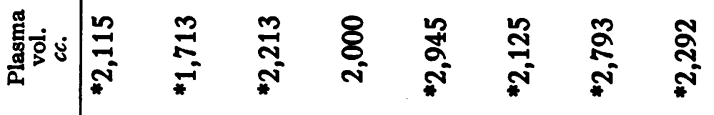

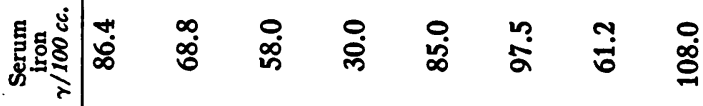

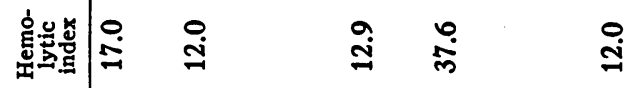

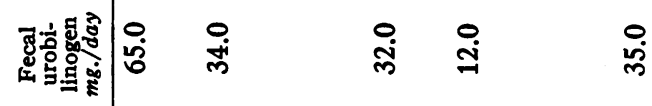

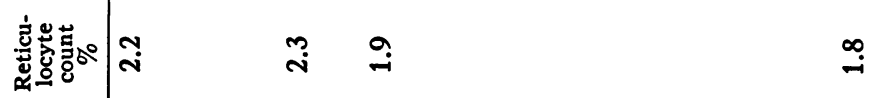

预

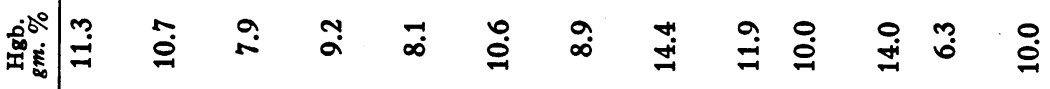

䜦

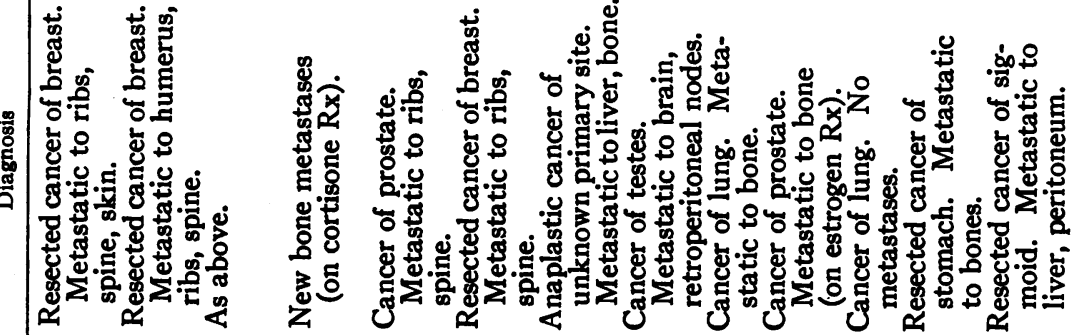

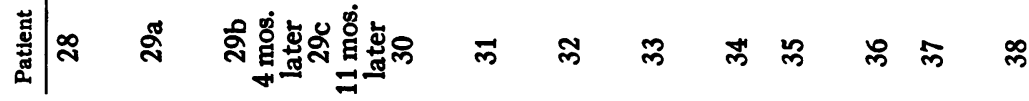


TABLE II

Correlation of the clinical status of the cancer with the severity of the anemia

\begin{tabular}{lccccc}
\hline \multicolumn{1}{c}{ Status of disease } & $\begin{array}{c}\text { Number of } \\
\text { cases }\end{array}$ & $\begin{array}{c}\text { Anemia } \\
\text { present* }\end{array}$ & $\begin{array}{c}\text { Anemia } \\
\text { mild }\end{array}$ & $\begin{array}{c}\text { Anemia } \\
\text { moderate }\end{array}$ & $\begin{array}{c}\text { Anemia } \\
\text { severe }\end{array}$ \\
\hline 1) Localized & 4 & None & None & None & None \\
\hline 2) Metastases present & 34 & 22 & 6 & 14 & 2 \\
\hline * Anemia mild (10.5 to 12.0 gm. per cent). \\
$\begin{array}{l}\text { (a) Moderate (7.0 to 10.4 gm. per cent). } \\
\text { severe (<7.0 gm. per cent). }\end{array}$
\end{tabular}

nique of Ashby as modified by Ebert and Emerson (18) and Young, Platzer, and Rafferty (19) was employed. Net inagglutinable counts were expressed as per cent transfused cells remaining at time $(t)$ using the net inagglutinable counts at 24 to 48 hours as the 100 per cent point. The mean life span of transfused red cells was roughly estimated by drawing a straight line through the main slope of the survival curve and noting where it intercepted the time axis.

(b) Chromium red cell survival studies. The survival of the patient's own red cells was determined by the $\mathrm{Cr}^{\mathrm{or}}$ method of Ebaugh, Emerson, and Ross (20) in two patients. Both blood and plasma samples were secured and counted 24 and 48 hours after transfusion. Thereafter, counts on whole blood were performed at intervals of 2 to 3 days for the first 2 to 3 weeks and subsequently once every 1 to 2 weeks. Corrections for chromium elution were made as recommended by Ebaugh, Emerson, and Ross (20).

\section{5) Iron metabolism studies}

(a) Serum iron determination. The serum iron concentration was determined by the method of Kitzes, Elvehjem, and Schuette (21). Normal levels by this technique in our laboratory were 70 to $155 \gamma$ per cc.

(b) Tissue iron demonstration. Sections of liver, spleen and bone marrow were stained for iron by the Berlin blue stain for hemosiderin on patients expiring of their disease.

(c) Radioiron turnover studies. $\mathrm{Fe}^{\mathrm{s}}$ secured from Abbott Laboratories, Oak Ridge, Tennessee, with specific activity of 2 to $5 \mu \mathrm{c}$. per $\mu \mathrm{g}$. was converted from ferric chloride to ferric ammonium-citrate. Then, 0.1 to $0.3 \mathrm{cc}$. of this sterilized material containing about 2.0 to $7.0 \mu \mathrm{g}$. of iron with a radioactivity of 7 to $11 \mu \mathrm{c}$. was incubated at $37^{\circ}$ for 30 minutes with 12 to $13 \mathrm{cc}$. of plasma obtained from a normal human subject. A 10-cc. aliquot of this plasma was injected intravenously from a calibrated syringe and needle. The disappearance of $\mathrm{Fe}^{\infty}$ from the plasma, the plasma iron turnover, the red cell utilization of $\mathrm{Fe}^{\mathrm{s}}$, the red cell iron turnover and the red cell iron renewal rate were determined by the method of Huff, Hennessy, Austin, Garcia, Roberts, and Lawrence (22). The plasma and red cell turnover was expressed as the $\frac{\mathrm{mg} \text {. iron } / \mathrm{hr} \text {. }}{\text { liter red cell mass }}$ and calculated from the following formula :

Plasma iron turnover $=$

$0.693 \times$ serum iron conc. ( $\mu$ g. per cc.) $\times$ plasma vol. (cc.) $\frac{T_{1} \text { (in hours) } \times 1,000 \times 24}{\text { liter red cell mass }}$

Red cell iron turnover $=\frac{\text { red cell iron turnover } \mathrm{mg} \cdot \text { per } \mathrm{hr} \text {. }}{\text { liter red cell mass }}$

The control values on 8 normal subjects to be alluded to are from Pollycove, Apt, and Ross (23). The experimental plan in the performance of these normal studies is similar to that used in the present study.

\section{6) Distribution and movement of $F e^{50}$ in the body}

Following the intravenous injection of radioactive iron, the localization of radioactivity in various organs was measured. Measurements of radioactivity were made over the heart, liver, spleen, sacrum and thigh at 30 to 60 minutes, 2, 4, and 6 hours, and at daily intervals over a period of 1 to 2 weeks.

\section{7) Measurement of radioactivity}

(a) Beta counting. Radioactive phosphorus labelled erythrocytes were counted as solid samples using a thin window beta-sensitive Geiger-Müller tube. The counting error was less than 1 per cent.

(b) Gamma counting. $\mathrm{Fe}^{\infty 0}$ and $\mathrm{Cr}^{\mathrm{s1}_{1}}$ samples were counted in the liquid state using a well-type scintillation counter (sodium iodide, thallium activated). When red cell samples were counted, saponin was added to produce hemolysis. Samples usually counted 5 to 15 times background and sufficient total counts were taken to give a statistical counting error of 1 to 2 per cent. In the 3 or 4-hour plasma samples from the plasma iron turnover studies, the concentration of $\mathrm{Fe}^{\mathrm{s}}$ was often so low that the statistical counting error was 5 to 10 per cent. External monitoring measurements were made with a one inch diameter, one inch deep thallium activated, sodium iodide scintillation crystal applied directly to the skin. Each site was counted for 1-minute intervals while the background was counted for 10 minutes. The background count ranged from 600 to 1,000 counts per minute and the body counts usually ranged from 6,000 to 18,000 counts per minute. 


\section{EXPERIMENTAL RESULTS}

\section{Hematological}

Of the patients studied, 22 out of 38 had an anemia, with the severity of the anemia listed in Table II. In 19 of the 22, the anemia was normochromic with a mean corpuscular hemoglobin concentration (MCHC) of 30 per cent or above (Table I). The remaining 3 patients had slightly reduced MCHC's ranging from 28.8 to 29.9 per cent. Twelve of the 16 patients without anemia had metastases and, despite extensive bone metastases, one of the 16 had normal hemoglobin values. The reticulocyte count was slightly elevated ( 3 to 5 per cent) in 4 patients. The Coombs test was negative and the serum bilirubin was within normal limits in all patients so studied.

\section{Radioiron studies}

(a) Plasma disappearance half-time of $F e^{59}$ $\left(T \frac{1}{2}\right)$. The plasma disappearance half-time of $\mathrm{Fe}^{59}\left(\mathrm{~T} \frac{1}{2}\right)$ ranged from 1.18 to 2.18 hours in normal subjects. In 27 of 37 studies on 33 cancer patients the $T \frac{1}{2}$ was more rapid than normal (Table I). The $\mathrm{T} \frac{1}{2}$ appeared to correlate fairly well with serum iron levels, the coefficient of correlation being 0.690 (Figure 1). Thus short $\mathrm{T} \frac{1}{2}$ 's were present when serum iron levels were depressed, and long $T \frac{1}{2}$ 's when serum iron levels were elevated. The relationship between $\mathrm{T}_{\frac{1}{2}}$ and serum iron concentration was further noted when

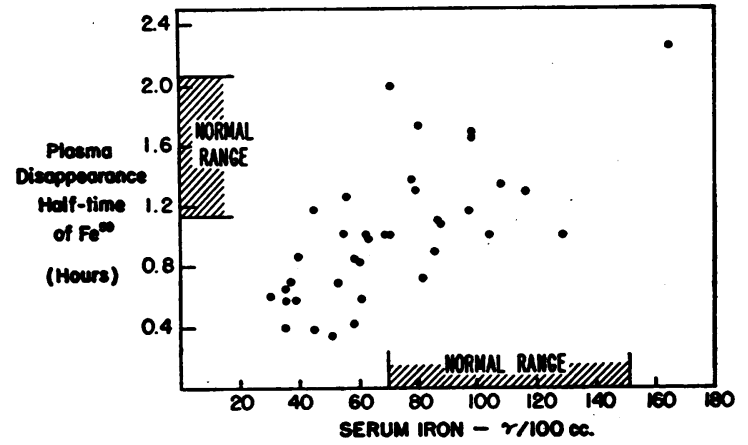

Fig. 1. Correlation of the Fe Plasma Disappearance Half-Tme with the Serum Iron Concentration in 33 Patients with Malignant Neoplasms

Each point in the above chart represents the serum iron concentration and the plasma disappearance halftime of a patient with malignant disease. The coefficient of correlation between the above two measurements was 0.690 . repeat radioiron studies were performed on the same patient after progression of the disease had occurred. Patient No. 12 was first studied when her disease was relatively quiescent and when the $\mathrm{T} \frac{1}{2}$ and the serum iron were both normal (Table I). Seventy-three days later, when her disease had become widely disseminated, a depressed serum iron level and a short $T_{\frac{1}{2}}$ was present. A similar finding was present in patient No. 29, who, with slow progression of her disease, had progressive lowering of serum iron levels concomitant with shorter $T \frac{1}{2}$ 's (Table I). Short $T \frac{1}{2}$ 's were not a good index of increased erythropoiesis. Thus in 17 of 37 studies, with slow T $\frac{1}{2}$ 's the daily rates of red cell production were either normal or actually decreased as measured by the red cell iron turnover (Table I). In only 9 out of 37 studies were the $T \frac{1}{2}$ 's within normal limits. Four patients in this group had quiescent disease, and anemia was present in only 2 such patients. $\mathrm{Pa}$ tient No. 17, with an elevated serum iron and decreased red cell production, had a longer than normal $\mathrm{T} \frac{1}{2}$.

(b) Plasma iron turnover. In 21 of 37 studies the plasma iron turnover (the amount of iron leaving the plasma per unit time) was within the normal range of 0.569 to $1.149 \mathrm{mg}$. iron per hour per liter red cells (Figure 2). In 11 patients the plasma iron turnover rate was increased over the normal, and in patients No. 1 and 27, the increase was 2 to 4 times normal. In only 2 of 37 studies was the plasma iron turnover decreased.

(c) The red cell utilization of injected $F e^{50}$. The incorporation of the injected $\mathrm{Fe}^{59}$ into newly formed red cells was normal (80 to 100 per cent) in 29 of 36 studies on 32 patients (Table I). Despite this normal red cell utilization of $\mathrm{Fe}^{59}$ in patients No. 16, 20 and $21 \mathrm{~b}$, the daily rate of red cell production was decreased when the red cell iron turnover was calculated. In only 7 of 36 studies was the red cell utilization of $\mathrm{Fe}^{59} \mathrm{de}$ creased. Only 5 per cent red cell utilization occurred in patient No. 17, who had the long $\mathrm{T} \frac{1}{2}$.

(d) The red cell iron turnover. In 20 of 36 studies the red cell iron turnover (the amount of iron entering into newly formed red cells per unit time) was within the normal range of 0.569 to $1.033 \mathrm{mg}$. iron per hour per liter red cells (Figure $2)$. In 11 studies the red cell iron turnover was increased. A 2 to 4 fold increase over normal oc- 


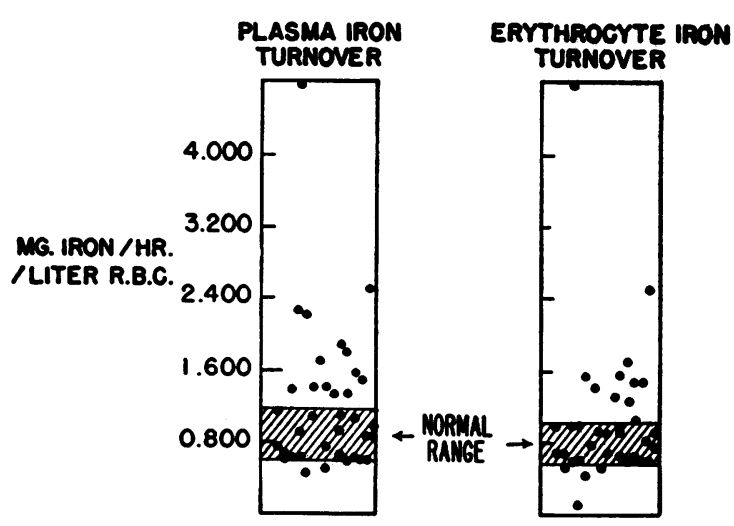

Fig. 2. The Rate of Plasma Iron Turnover and the Rate of Red Blood Cell Iron Turnover in 33 Patients with Neoplastic Disease

curred in patients No. 1 and 27. A definite increase in red cell iron turnover was also noted in patients No. 9 and 25 despite the presence of normal hemoglobin levels (Table I). A decrease in red cell iron turnover was noted in 5 patients ranging from 0.114 to $0.534 \mathrm{mg}$. iron per hour per liter red cells. Anemia was present in only 2 of these patients. A profound decrease in red cell iron turnover was noted in patient No. 17 alluded to previously, in whom subsequent autopsy showed complete bone marrow replacement with lymphosarcoma.

(e) Red cell renewal rate. The red cell renewal rate (the fraction of red cells renewed daily) was increased over the normal rate of 1.1 to 1.8 per cent in 20 studies on 18 patients (Table I). A very marked increase in red cell renewal rate, i.e., 4 to 8 times normal, was noted in patients No.

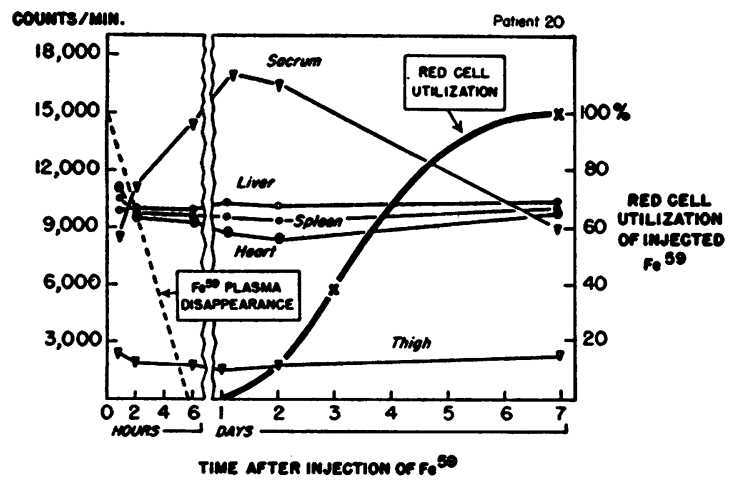

Fig. 3. Normal Pattern of Fe Distribution in a Patient with Fibromyxosarcoma

Note the early rise and subsequent decline in sacral radioactivity.
1 and 27 associated with a 2 to 4 fold increase in red cell production. Patients No. 9 and 25, with normal hemoglobin values and increased red cell iron turnover values, demonstrated red cell renewal rates that were almost twice normal. In all twenty studies with increased red cell renewal rates metastases were present, whereas metastases were discovered in only nine of the sixteen studies with normal renewal rates. Anemia was present in seventeen of the twenty cases with increased red cell renewal rates, whereas it was observed in only three of the sixteen cases with normal renewal rates.

\section{External monitoring}

The localization of iron in the body, and changes in this localization with the passage of time, were studied by external monitoring in 8 patients. An early rise in sacral activity followed by a gradual decline (Figure 3 ) occurred in 5 patients (No. $11,12,15,16$ and 20). This is thought to be representative of functioning erythropoietic bone marrow and is similar to the pattern found in normal subjects. Three other patients (No. 5, 17 and 29) demonstrated abnormalities in the distribution of $\mathrm{Fe}^{59}$. Patient No. 5, whose hemolytic index was increased, showed an early and sustained concentration of $\mathrm{Fe}^{59}$ over the spleen without a sacral concentration of $\mathrm{Fe}^{59}$ (Figure 4). Patient No. 17, whose bone marrow was replaced by lymphosarcoma, also demonstrated a failure of sacral uptake of $\mathrm{Fe}^{59}$ with a pooling of radioiron

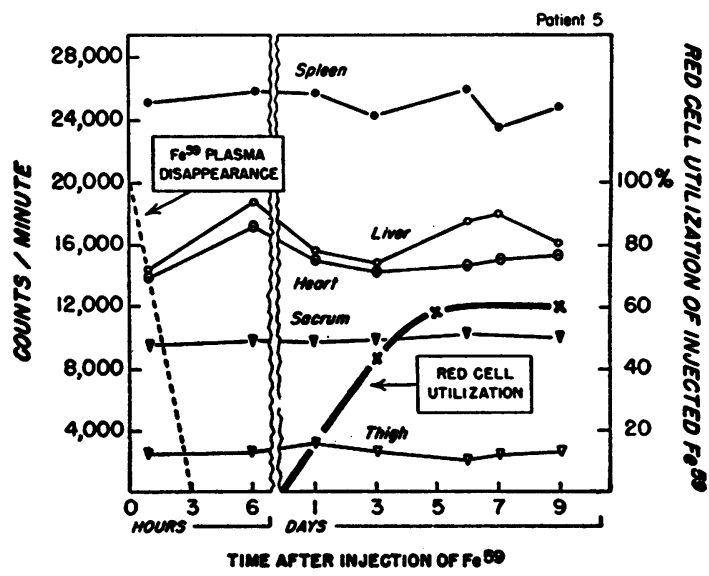

Fig. 4. Splenic Concentration of Fe $\mathrm{F}^{50}$ in a Patient With an Elevated Hemolytic INDEx

Note also the absence of sacral uptake of $\mathrm{Fe}^{\mathrm{se}}$. 


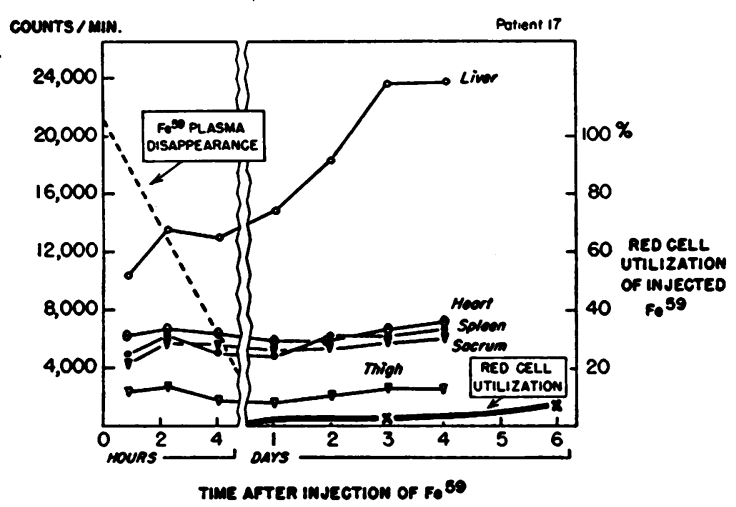

Fig. 5. Hepatic Pooling of $\mathrm{Fe}^{\infty}$ in a Patient with BONE MARROW REPLACEMENT bY LyMPHOSARCOMA

Note also the absence of sacral concentration of $\mathrm{Fe}^{\mathrm{se}}$.

in the liver (Figure 5). Lastly, patient No. 29 with wide-spread lumbosacral bone metastases, demonstrated a failure of sacral uptake unassociated with any increase in liver or spleen $\mathrm{Fe}^{59}$ uptake (Figure 6). Despite the absence of sacral concentration of $\mathrm{Fe}^{50}$, this patient had normal red cell utilization of $\mathrm{Fe}^{59}$.

In patients No. 20 with a fibromyxosarcoma in the right scapular region, and No. 15 with cancer of the left breast, external monitoring revealed no appreciable concentration of the injected $\mathrm{Fe}^{5 \mathrm{~g}}$ in the tumor areas. In patient No. 10 with bronchogenic carcinoma, and patient No. 11 with adenocarcinoma of the bronchus, $\mathrm{Fe}^{59}$ was injected 24 hours before surgery. From the resected tumor, 4 to 8-gm. aliquots of the entire tumor were placed in test tubes and assayed for radioactivity in a well counter. Blood concentration of $\mathrm{Fe}^{8 \mathrm{~g}}$ was negligible at this time. No appreciable concentration of $\mathrm{Fe}^{60}$ was found in either of these tumors.

\section{Iron metabolism}

(a) Serum iron concentration. The serum iron concentration ranged from 30.0 to $165.0 \gamma$ per 100 cc. with a median of $65.0 \gamma$ per $100 \mathrm{cc}$. in $33 \mathrm{pa}$ tients, as compared with the normal range of 70 to $155 \gamma$ per $100 \mathrm{cc}$. Depressed serum iron levels were found in 17 patients. The incidence and the degree of depression could not be correlated with the presence or extent of metastatic tumor. Thus, 11 of the 16 patients with normal serum iron levels had widespread disease, as compared with 12 of 17 patients with widespread disease who had

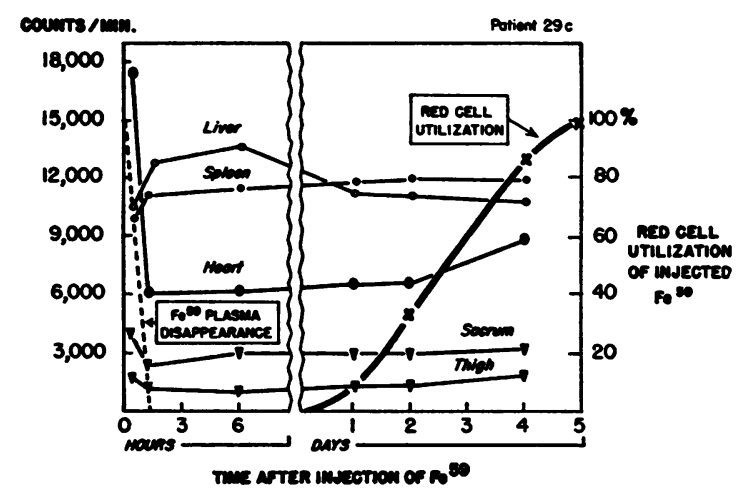

Fig. 6. Absence of Sacral Concentrations of Fe in a Patient with Widespread Lumbosacral Bone Metastases

depressed serum iron values. However, when measurements were repeated during the course of tumor spread, a progressive fall in serum iron concentration could usually be demonstrated. This phenomenon is well illustrated in case No. 12, who, when first studied, was asymptomatic and had a normal serum iron. Seventy-three days later, following widespread dissemination of the disease process, the patient's serum iron had decreased to $34.6 \gamma$ per $100 \mathrm{cc}$. (Figure 7). Six other patients demonstrated similar lowering of serum iron levels with progression of their disease. Contrariwise, with improvement in the clinical state of the patient, serum iron levels tended to rise towards normal (Figure 7). Thus, in patient No. 10 with bronchogenic carcinoma without metastases, the serum iron concentration was $35.0 \gamma$ per $100 \mathrm{cc}$. at the time of the first study. Eight months later, following complete surgical removal of the carcinoma, the serum iron had risen to a low normal level of $89.7 \gamma$ per $100 \mathrm{cc}$.

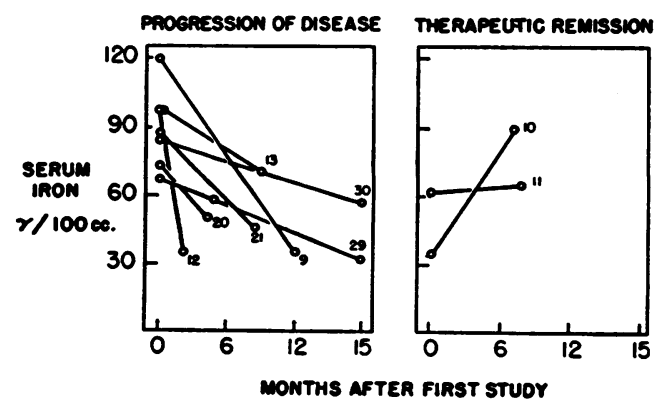

Fig. 7. Changes in Serum Iron Levels Assoctated with Changes in the Cinical. Status of Malignant Neoplasms in Nine Patients 
TABLE III

The status of the iron stores in 10 cancer patients

\begin{tabular}{|c|c|c|c|c|c|c|}
\hline \multirow[b]{2}{*}{$\begin{array}{l}\text { Patient } \\
\text { No. }\end{array}$} & \multirow[b]{2}{*}{$\begin{array}{c}\text { Serum iron } \\
\text { concentration }\end{array}$} & \multirow[b]{2}{*}{ Transfused } & \multirow{2}{*}{$\begin{array}{l}\text { Evidence of } \\
\text { increased } \\
\text { red cell } \\
\text { destruction }\end{array}$} & \multicolumn{3}{|c|}{ Storage iron } \\
\hline & & & & Liver & Spleen & $\begin{array}{c}\text { Bone } \\
\text { marrow }\end{array}$ \\
\hline $\begin{array}{r}3 \\
4 \\
7 \\
20 \\
23 \\
26 \\
27 \\
31 \\
32 \\
34\end{array}$ & $\begin{array}{l}\text { Decreased } \\
\text { Normal } \\
\text { Decreased } \\
\text { Decreased } \\
\text { Decreased } \\
\text { Normal } \\
\text { Decreased } \\
\text { Normal } \\
\text { Decreased }\end{array}$ & $\begin{array}{l}\text { No } \\
\text { No } \\
\text { No } \\
\text { Yes (4)* } \\
\text { No } \\
\text { Yes (2) } \\
\text { Yes (2) } \\
\text { Yes (2) } \\
\text { No } \\
\text { Yes (2) }\end{array}$ & $\begin{array}{l}\text { No } \\
\text { Yes } \\
\text { Yes } \\
\text { No } \\
\text { Yes } \\
\text { Yes } \\
\text { Yes } \\
\text { Yes } \\
\text { Yes } \\
\text { Yes }\end{array}$ & $\begin{array}{l}\text { Decreased } \\
\text { Normal } \\
\text { Decreased } \\
\text { Decreased } \\
\text { Increased } \\
\text { Decreased } \\
\text { Normal } \\
\text { Normal } \\
\text { Normal } \\
\text { Decreased }\end{array}$ & $\begin{array}{l}\text { Normal } \\
\text { Normal } \\
\text { Increased } \\
\text { Normal } \\
\text { Increased } \\
\text { Absent } \\
\text { Increased } \\
\text { Increased } \\
\text { Decreased } \\
\text { Increased }\end{array}$ & $\begin{array}{l}\text { Increased } \\
\text { Normal } \\
\text { Normal } \\
\text { Normal } \\
\text { Decreased } \\
\\
\text { Increased } \\
\text { Normal } \\
\text { Decreased }\end{array}$ \\
\hline
\end{tabular}

* Number of pints of transfused blood.

Anemia and hypoferremia were associated findings in 10 of 33 patients (Table I). Anemia in the presence of a normal serum iron concentration was found in 7 patients, while hypoferremia with out anemia occurred in 6 other patients. Ten patients displayed neither anemia nor hypoferremia.

\section{Determination of storage iron}

A semi-quantitative estimate of storage iron was accomplished in 10 cases by examining postmortem sections of liver, spleen and bone marrow stained for hemosiderin with Berlin blue. In 7 of 10 patients the iron stores appeared to be normal, while in two others slightly increased amounts were found (Table III). A decrease in the quantity of storage iron was found in patient No. 22. Despite the presence of normal amounts of storage iron, the serum iron concentration was decreased in 6 patients. Two of the 3 patients, who had de-

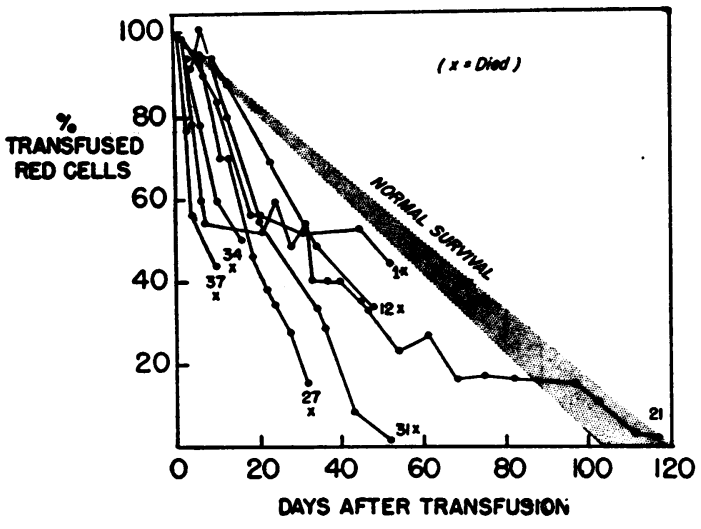

Fig. 8. Increased Destruction of Normal Transfused Red Cells in Seven Cancer Patients creased mean corpuscular hemoglobin concentrations (No. 23 and 32), had normal or increased amounts of storage iron. The one patient with the decreased amount of storage iron had a low normal serum iron level.

\section{Fecal urobilinogen studies}

The hemolytic index was elevated in 6 of 13 patients (Table I). In five of these 6 patients, additional evidence for increased red cell destruction was secured from measurements of red cell survival and $\mathrm{Fe}^{59}$ studies.

\section{Red cell survival studies}

Increased red cell destruction was found in 5 patients, the life span of transfused erythrocytes ranging from 25 to 80 days, in contrast to the

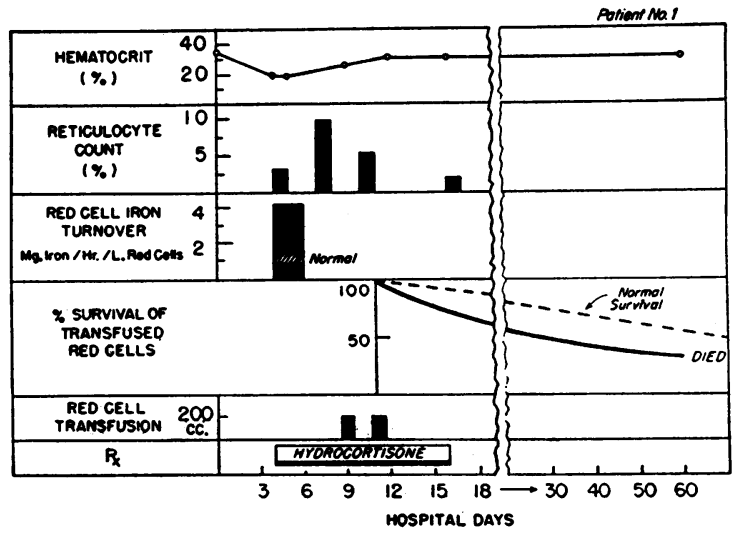

Fig. 9. Hematological, Radioiron, and Red Cell Survival Studies on a Patient with Disseminated Carcinoma of the Prostate

See text for explanation. 


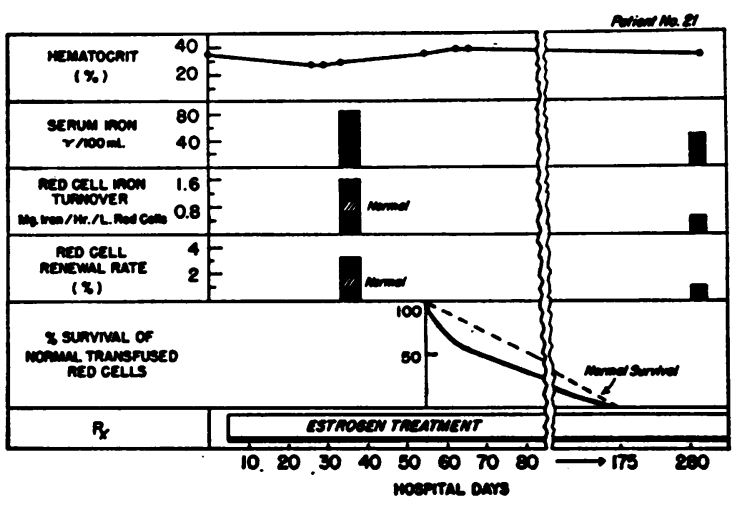

Fig. 10. Hematological, Radioiron, and Red Cell Survival Studies on a Patient with Widespread Carcinoma

See text for explanation.

normal 120-day survival period (Figure 8). $\mathrm{Pa}$ tients No. 1 and 21 destroyed donor cells rapidly during the initial phase of the study, the rate of hemolysis subsequently returning to normal. As shown in Figure 9, during the first 18 days following transfusion, patient No. 1 eliminated the donor cells at a rate of 2.8 per cent per day, the daily loss thereafter being reduced to 0.85 per cent. Patient No. 21 showed a daily loss of donor cells of 5.6 per cent per day for the first 10 days, and a normal red cell survival subsequently (Figure 10). Red cells survived normally in 5 patients (No. 24, 29, 35, 36, and 38), 4 of whom had metastases and anemia. Patient No. 38, in the face of severe anemia and disseminated cancer,

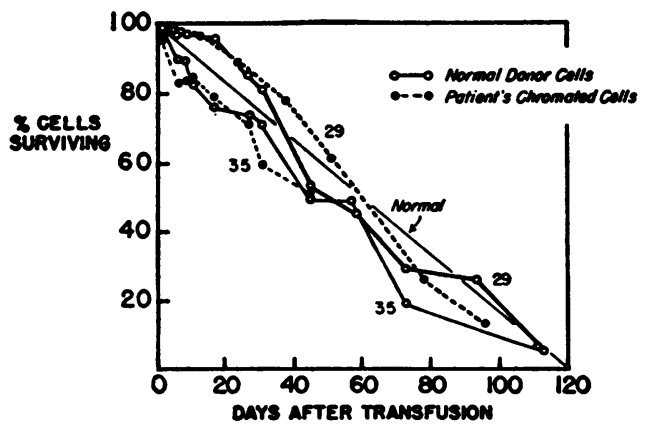

Fig. 11. The Survival of Normal Donor Red Cells and the Red Cells of Two Patients with DissemiNATEd CaRcinoma

The above data indicate that the survival of normal transfused red cells measured by the red cell differential agglutination technique, and the patient's red cells measured by the $\mathrm{Cr}^{\mathrm{s1}}$ technique, were both normal. exhibited a normal red cell survival during the terminal month of his illness. Patient No. 29 was studied on two occasions, 11 months apart, during which time hemoglobin levels were stable despite the progression of the carcinoma. Both studies were normal. The survival of normal donor cells, based on Ashby counts and the patient's own erythrocytes labelled with $\mathrm{Cr}^{51}$, were measured in patients No. 29 and 35. The results were normal in each instance (Figure 11).

\section{Serial observation during the advance of cancer}

(a) Patient No. 12 had had a radical mastectomy for cancer of the breast three years prior to this study. A solitary metastasis to the left orbit, first discovered eight months previously, was the only evidence of dissemination of the cancer. At the time of the first $\mathrm{Fe}^{58}$ study, the patient was asymptomatic, with normal serum iron and hemoglobin levels, normal $\mathrm{T}_{\frac{1}{2}}$ of $\mathrm{Fe}^{59}$ and normal rates of red cell production and destruction (Figure 12). Studies were repeated seventy-three days later when there was obvious dissemination of the cancer to lungs, liver and femur. Anemia had developed, the concentration of serum iron had de-

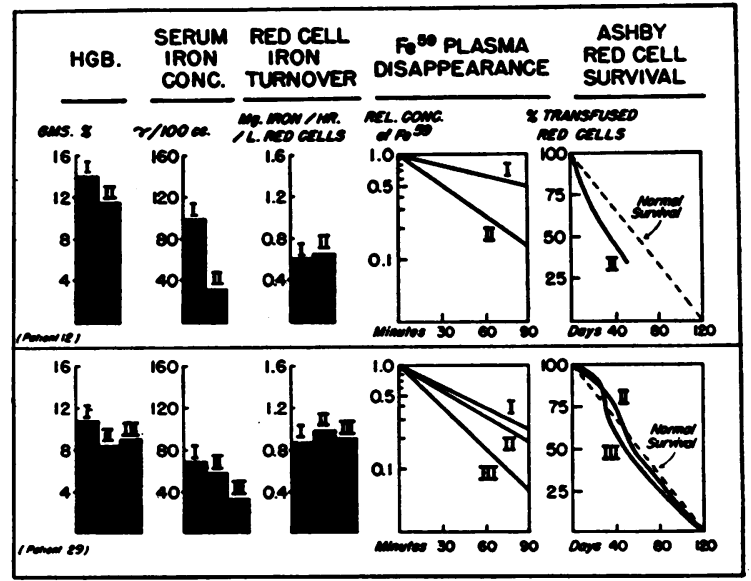

Fig. 12. The Effect of Rapid and Slow Dissemination of Metastatic Cancer on Hemoglobin Levels, Iron Metabolism and Red Cell Survival in Two Different Patients

Patient No. 12 First study (I) Disease quiescent; Second Study (II) 73 days later after rapid dissemination of carcinoma.

Patient No. 29 First study (I) Widespread bone metastases present; Subsequent study (II) 4 months later, no clinical change; Final study (III) 11 months later after the appearance of new bone metastases. 
clined and the $\mathrm{T} \frac{1}{2}$ of $\mathrm{Fe}^{50}$ had become rapid. The red cell iron turnover was discovered to be increased, but the red cell renewal rate had not changed. A survival study demonstrated increased red cell destruction, the estimated life span of normal donor cells averaging between 75 and 80 days (Figure 12). The patient died 48 days after the transfusion study had started.

(b) Patient No. 29, had had a radical mastectomy in 1948 for a cancer of the breast. The patient was studied three years later when metastases were widespread. The first study revealed anemia, a slight reduction of serum iron, a moderately short $\mathrm{T}_{\frac{1}{2}}$ of $\mathrm{Fe}^{58}$, normal red cell production and a questionable increase in red cell destruction (Figure 12). Four months later, her clinical status having remained stationary, the patient was re-studied. A moderate decline in hemoglobin and serum iron levels and a reduction of $\mathrm{T}_{\frac{1}{2}}$ of $\mathrm{Fe}^{59}$ were discovered. A survival study demonstrated normal life span of the transfused red cells. Eleven months later, new skin and bone metastases were present. The serum iron showed further depression, and shortening of the $\mathrm{T}_{\frac{1}{2}}$ was more pronounced, whereas the survival of donor and patient's cells remained normal.

(c) Patient No. 21, a 62-year-old male, was found to have carcinoma of the prostate with widespread bone metastases and was started on estrogen treatment. On treatment the patient's bone pain practically disappeared, although the $\mathrm{x}$-ray findings remained unchanged. During the first 4 weeks in the hospital, in the absence of blood loss, a progressive decrease in hematocrit and hemoglobin levels was noted (Figure 10). Radioiron studies were performed $4 \frac{1}{2}$ weeks after admission at which time hemoglobin levels had stabilized at $8.5 \mathrm{gm}$. per cent. These studies revealed a low normal serum iron concentration and increased rates of red cell production and destruction (Figure 10). A red cell survival study, which was begun at a time when the hemoglobin and hematocrit levels were slowly rising, revealed increased red cell destruction during the first 10 days, but thereafter the remaining transfused cells survived normally. Eight months later, the disease having been relatively static, the serum iron was depressed and the $\mathrm{T} \frac{1}{2}$ of $\mathrm{Fe}^{59}$ shorter. Red cell production was now slightly reduced but red cell destruction, previously rapid, was normal.

\section{DISCUSSION}

Anemia, not attributable to blood loss or infection, was present in approximately 60 per cent of the cancer patients in this study. The general incidence of this type of anemia is unknown since earlier statistical data have not excluded blood loss or infection as a cause. As our patients were not consecutive hospital cancer admissions, the incidence cannot be computed from our findings. In this study, in contrast to other reports (24), patients with anemia have usually shown absolute decreases in red cell mass. Morphologic observations on the bone marrow usually revealed normal to increased cellularity, despite the presence of marrow metastases and anemia. This is similar to the observations of other investigators who have found no correlation between the presence of anemia, the cellularity of the bone marrow, or the extent of bone marrow metastases (1-3).

Evidence pointing to increased red cell destruction as one of the mechanisms responsible for this anemia has been secured from fecal urobilinogen, red cell survival and $\mathrm{Fe}^{59}$ studies. In 2 patients with evidence of increased hemolysis from radioiron data, the hemolytic index calculated from the fecal urobilinogen excretion was normal. The relative insensitivity of fecal urobilinogen analysis in demonstrating minor increases in daily red cell destruction as measured by the red cell survival techniques has also been noted by Ross, Crockett, and Emerson (7) in their studies in leukemia patients.

In 5 of 13 studies involving the transfusion of normal red cells into cancer patients the survival of these cells was shortened, their life span ranging from 25 to 80 days, confirming previous observations $(4-6)$. The hemolytic rate returned to normal in 2 patients, both of whom had widespread metastatic disease and anemia. The cortisone or estrogen treatment may have been responsible for this improvement.

Further evidence for increased red cell destruction was secured from the definite increase in red cell renewal rates in two-thirds of the patients studied. Patients with very low serum iron levels and rapid $\mathrm{T} \frac{1}{2}$ 's of $\mathrm{Fe}^{59}$, who show slight increases in red cell renewal rates, do not necessarily have increased rates of red cell destruction as exemplified by patient No. 29. The apparent increase in 
red cell renewal rate in such cases is probably explained by a technical error in the $\mathrm{Fe}^{59}$ technique. Possible sources of error include difficulty in the following: (a) measuring the $\mathrm{T}_{\frac{1}{2}}$ accurately when it is brief; (b) variation in results obtained by the Kitzes, Elvehjem, and Schuette (21) method of determining serum iron, the error approaching 10 per cent for levels between 30 and $70 \gamma$ per $100 \mathrm{cc}$. of serum, levels which are typical of cases with rapid $T \frac{1}{2}$ 's. The $T \frac{1}{2}$ and the serum iron concentration are two of the chief parameters in the calculation of red cell renewal rates, and errors in the estimation of either may be responsible for the discrepant finding of a rapid red cell renewal rate in patients without other evidence of increased red cell destruction. Even if this small group of patients were eliminated from consideration, more than half of the patients studied demonstrated evidence of increased red cell destruction.

The mechanism of increased hemolysis in cancer patients is unknown. Coombs tests failed to demonstrate any antibody mechanism which might have played a role in the increased red cell destruction, our experience in this regard paralleling that of Hyman (6). Weil (25) and Gross (26, 27 ) reported that extracts of tumor tissue hemolyzed red cells in vitro. Whether or not an analogous situation exists in vivo causing injury to circulating red cells and chronic hemolytic anemia is another possibility to be explored. Large doses of $x$-ray and radium used in the treatment of cancer of the cervix have been reported to increase the rate of red cell destruction (5). In as much as some of our patients with increased red cell destruction had received irradiation therapy prior to study, a causal relationship of this type cannot be excluded.

Hypoferremia was a frequent but not invariable finding in cancer patients, as others have reported $(8-10,28)$, the depression of plasma iron concentration tending to parallel in degree the extent of growth and the metastatic spread of the neoplasm. The fact that the serum iron concentration rose in patient No. 10 following surgical removal of tumor tissue is evidence that the tumor itself was in some way responsible for the hypoferremia.

The finding of normal or increased amounts of hemosiderin iron in sections of liver, spleen, and bone marrow tends to exclude iron deficiency as the cause of hypoferremia and anemia in our patients. Sandberg, Gross and Holly $(29,30)$ reported normal to increased amounts of iron in the liver and spleen of patients dying with disseminated carcinoma and anemia, the amount often appearing to be excessive in proportion to the degree of anemia. Our findings partially confirm these observations, although the quantity of iron found in our cases was less. Since the organs analyzed by Sandberg, Gross and Holly contained indeterminate amounts of hemoglobin iron, their large values might be explained in part on that basis.

The depression of serum iron levels in the presence of normal or slightly increased storage iron in cancer has its analogy in acute and chronic infections $(31,32)$ but the mechanism responsible for the phenomenon is not understood. Depletion of serum iron as a result of its extraction by neoplasms with an increased avidity for that element is unlikely in view of the fact that accumulation of $\mathrm{Fe}^{59}$ in tumor tissue has not been demonstrable in any of the cases we have investigated from this standpoint (Cases No. 10, 11, 15 and 20). Moreover, chemical analyses of various malignant tumors described in the literature (30, $33,34)$ have demonstrated that the concentration of iron in such tissues is low. There is evidence to incriminate the reticulo-endothelial system in the genesis of the hypoferremia found in experimentally produced acute inflammation in the dog $(35,36)$. Whether a similar mechanism is operative in the chronic cancer patient is uncertain.

The $\mathrm{T}_{\frac{1}{2}}$ of injected $\mathrm{Fe}^{59}$ was abnormally short in two-thirds of the patients studied. A fair correlation existed between serum iron levels and the $\mathrm{T} \frac{1}{2}$, with a prolonged $\mathrm{T} \frac{1}{2}$ associated with an increased serum iron, and a short $\mathrm{T}_{\frac{1}{2}}$ with a decreased serum iron. That this is not uniform is seen in conditions like pernicious anemia, hemolytic anemias, and infectious hepatitis $(37,38)$ where normal to elevated serum iron values may coexist with short $\mathrm{T}_{2} \frac{1}{2}$ 's. Contrary to the observations of Wasserman, Rashkoff, Leavitt, Mayer, and Port (37), short $\mathrm{T}_{\frac{1}{2}}$ 's do not always signify increased rates of erythropoiesis. It would appear that the disappearance rate of injected $\mathrm{Fe}^{58}$ is predominantly affected by two factors: the level of serum iron, and the rate of erythropoiesis. A major change in either or both factors alters the 
$T_{\frac{1}{2}}$. Thus, depression of the serum iron from either iron deficiency, cancer, or infection is associated with a short $\mathrm{T}_{\frac{1}{2}}(37)$, whereas with elevation of the serum iron, as in hemochromatosis, a long $T_{\frac{1}{2}}$ is found (39). When erythropoiesis is increased, as in polycythemia vera or hemolytic anemia, a short $T \frac{1}{2}$ is to be expected $(23,37)$; conversely, in the hypoplastic anemias the $\mathrm{T} \frac{1}{2}$ is prolonged $(23,37)$.

External monitoring revealed normal patterns of $\mathrm{Fe}^{59}$ distribution in 5 patients, 2 of whom were anemic. Three other anemic patients exhibited abnormal localization sites of the injected $\mathrm{Fe}^{59}$. One of these, with extensive metastases involving the lumbosacral spine, failed to concentrate the $\mathrm{Fe}^{59}$ in the sacral marrow despite normal red cell utilization of the radioiron. Bone marrow sites uninvolved with tumor must have accounted for the normal utilization of $\mathrm{Fe}^{59}$. Thus, impaired utilization of $\mathrm{Fe}^{59}$ by the total bone marrow cannot be assumed from the absence of sacral concentration of $\mathrm{Fe}^{59}$ in patients with metastatic neoplasms. Another patient with signs of increased red cell destruction promptly proceeded to concentrate $\mathrm{Fe}^{59}$ in the spleen to a striking degree, the sacral concentration characteristic of normal subjects failing to appear. The spleen in this patient may have served as an erythroblastic organ, which could explain the early $\mathrm{Fe}^{59}$ uptake. The high spleen concentration of $\mathrm{Fe}^{59}$ for the first nine days may reflect erythroclastic activity, i.e., destruction of newly formed red cells labelled with $\mathrm{Fe}^{59}$. Combination erythroblastic-erythroclastic spleens have been described by Elmlinger, Huff, Tobias, and Lawrence (40) in myelofibrosis and cirrhosis with superimposed hemolytic anemia. In a third patient with diffuse marrow replacement by lymphosarcoma and marked depression of erythropoiesis the sacrum bone marrow failed to concentrate $\mathrm{Fe}^{59}$, whereas a progressive and sustained pooling of the isotope occurred in the liver. Presumably this represents the storage of $\mathrm{Fe}^{59}$ that is not to be used for hemoglobin production by the tumor-ridden marrow and resembles the pattern described by Elmlinger, Huff, Tobias, and Lawrence (40) in patients with refractory anemia and decreased erythropoiesis.

It would appear that anemia in cancer may be caused by different pathophysiological mechanisms. For example, increased red cell destruc- tion, associated with normal or increased rates of red cell production, is commonly found in these cases. The concept of bone marrow depression due to "replacement" by cancer cells or "toxic" depression by a tumor metabolite is not substantiated by this study. Although red cell production may be increased 2 to 4 fold, it may not keep pace with the increased red cell destruction, the hemoglobin concentration declining to the level at which production and destruction rates are matched. A characteristic abnormality of the patient with cancer is failure to compensate fully for an increased rate of red cell destruction, whether the latter is mild or severe. Thus, the 6 to 8 fold increase in erythropoietic activity displayed by a normal bone marrow after acute hemorrhage, or by the bone marrow of a patient with hereditary spherocytosis (41) in response to anemia, is not seen in cancer. In spite of morphological and physiological evidence of hyperactive erythropoietic activity, the marrow of the cancer patient actually shows "functional inadequacy" in the face of demand. That this apparent failure may not be absolute is suggested by the reticulocyte response and the rise in hemoglobin in some anemic cancer patients treated with cobalt (1). Moreover, a few of these patients are capable of compensating for increased hemolysis without anemia developing. This state of hemolysis in cancer has also been described by Sheets, Hamilton, DeGowin, and Janney (5).

As had been assumed in the past the anemia associated with cancer can result primarily from a decrease in red cell production. This situation is most apt to arise in patients with widespread metastases but can occur without gross evidence of marrow involvement. However, the concept of bone marrow replacement as a common cause of anemia is untenable even when decreased red cell production can be demonstrated. It is possible that inadequacy of marrow activity in cancer, whether relative or absolute, merely reflects an alteration in the homeostatic mechanism which determines the level of hemoglobin concentration or red cell mass in the tumor host.

\section{SUMMARY}

1. Evidence of increased red cell destruction based on measurements of fecal urobilinogen ex- 
cretion was found in 6 of 13 patients with malignant neoplasms. Increased red cell destruction was also found in 7 of 12 patients by red cell survival studies.

2. The rate of red cell production, as measured by radioiron and red cell survival studies, was normal or increased in 29 patients in this series, but usually failed to compensate for the increased hemolysis with anemia resulting. Thus, a "functional inadequacy" of erythropoiesis in the face of a red cell deficit may be considered the fundamental mechanism of anemia in neoplastic disease.

3. Anemia was solely attributable to deficient red cell production in 9 patients, 4 of whom were totally or nearly free of marrow metastases.

4. Hypoferremia associated with normal quantities of storage iron was a common finding in patients with cancer, the concentration of serum iron becoming progressively lower with dissemination of the tumor. Hypoferremia was usually, but not invariably, accompanied by anemia.

\section{REFERENCES}

1. Shen, S. C., and Homburger, F., The anemia of cancer patients and its relation to metastases to the bone marrow. J. Lab. \& Clin. Med., 1951, 37, 182.

2. Weisberger, A. S., and Heinle, R. W., Study of fixed tissue sections of sternal bone marrow obtained by needle aspiration. III. Metastatic carcinoma in sternal bone marrow. Am. J. M. Sc., 1949, 217, 263.

3. Vaughn, J. M., Leuco-erythroblastic anaemia. J. Path. \& Bact., 1936, 42, 541.

4. Brown, G. M., The pathogenesis of secondary anaemias. Canad. M. A. J., 1950, 62, 472.

5. Sheets, R. F., Hamilton, H. E., DeGowin, E. L., and Janney, C. D., Studies with inagglutinable erythrocyte counts. V. Spontaneous and $\mathrm{x}$-ray induced hemolysis in malignancy. J. Clin. Invest., 1954, 33, 179.

6. Hyman, G. A., Studies on anemia of disseminated malignant neoplastic disease. I. The hemolytic factor. Blood, 1954, 9, 911.

7. Ross, J. F., Crockett, C. L., Jr., and Emerson, C. P., The mechanism of anemia in leukemia and malignant lymphoma. J. Clin. Invest., 1951, 30, 668.

8. Heilmeyer, L., and Plötner, K., Das Serumeisen und das EisenmangelKrankheit. (Pathogenese, symptomatologie und therapie). Jena, G. Fischer, 1937.

9. Laurell, C.-B., Studies on the transportation and metabolism of iron in the body, with special reference to the iron-binding component in human plasma. Acta physiol. Scandinav., 1947, 14, Supp. 46.
10. Tötterman, L. E., Intravenous iron tolerance tests in malignant neoplasms. Their value for diagnosis and for antianemic treatment with iron, vitamin $\mathrm{C}$ and penicillin. Acta med. Scandinav., 1951, 140, 265.

11. Wintrobe, M. M., Clinical Hematology. 3rd. ed., Philadelphia, Lea and Febiger, 1951.

12. Evelyn, K. A., A stabilized photoelectric colorimeter with light filters. J. Biol. Chem., 1936, 115, 63.

13. Malloy, H. T., and Evelyn, K. A., The determination of bilirubin with the photoelectric colorimeter. J. Biol. Chem., 1937, 119, 481.

14. Schwartz, S., Sborov, V., and Watson, C. J., Studies of urobilinogen. IV. The quantitative determination of urobilinogen by means of the Evelyn photoelectric colorimeter. Am. J. Clin. Path., 1944, 14, 598.

15. Miller, E. B., Singer, K., and Dameshek, W., Use of the daily fecal output of urobilinogen and the hemolytic index in the measurement of Hemolysis. Arch. Int. Med., 1942, 70, 722.

16. Gibson, J. G., 2nd, and Evans, W. A., Jr., Clinical studies of the blood volume. I. Clinical application of a method employing the azo dye "Evans blue" and spectrophotometer. J. Clin. Invest., 1937, 16, 301.

17. Chapin, M. A., and Ross, J. F., The determination of the true cell volume by dye dilution, by protein dilution, and with radioactive iron. The error of the centrifuge hematocrit. Am. J. Physiol., 1942, 137, 447.

18. Ebert, R. V., and Emerson, C. P., Jr., A clinical study of transfusion reactions: The hemolytic effect of group-O blood and pooled plasma containing incompatible isoagglutinins. J. Clin. Invest., 1946, 25, 627.

19. Young, L. E., Platzer, R. F., and Rafferty, J. A., Differential agglutination of human erythrocytes. J. Lab. \& Clin. Med., 1947, 32, 489.

20. Ebaugh, F. G., Jr., Emerson, C. P., and Ross, J. F., The use of radioactive chromium 51 as an erythrocyte tagging agent for the determination of red cell survival in vivo. J. Clin. Invest., 1953, 32, 1260.

21. Kitzes, G., Elvehjem, C. A., and Schuette, H. A., The determination of blood plasma iron. J. Biol. Chem., 1944, 155, 653.

22. Huff, R. L., Hennessy, T. G., Austin, R. E., Garcia, J. F., Roberts, B. M., and Lawrence, J. H., Plasma and red cell iron turnover in normal subjects and in patients having various hematopoietic disorders. J. Clin. Invest., 1950, 29, 1041.

23. Pollycove, M., Apt, L., and Ross, J. F., Unpublished observations.

24. Berlin, N. I., Hyde, G. M., Parsons, R. J., and Lawrence, J. H., The blood volume in various medical and surgical conditions. New England J. Med., 1952, 247, 675.

25. Weil, R., Hemolytic properties of organ and tumor extracts. J. Med. Research, 1907, 16, 287. 
26. Gross, L., Hemolytic action of mouse mammary carcinoma filtrate on mouse erythrocytes in vitro. Proc. Soc. Exper. Biol. \& Med., 1947, 65, 292.

27. Gross, L., Destructive action of human cancer extracts on red blood cells in vitro. Proc. Soc. Exper. Biol. \& Med., 1949, 70, 656.

28. Bateman, J. C., Klapp, C. T., and Miesfeld, P., Serum iron response to pituitary adrenal agents in normal and in cancer patients. Blood, 1952, 7, 1093.

29. Sandberg, M., Gross, H., and Holly, O. M., Changes in retention of copper and iron in liver and spleen in chronic diseases accompanied by secondary anemia. Arch. Path., 1942, 33, 834.

30. Gross, H., Sandberg, M., and Holly, O. M., Changes in copper and iron retention in chronic diseases accompanied by secondary anemia. II. Changes in liver, spleen and stomach. Am. J. M. Sc., 1942, 204, 201.

31. Cartwright, G. E., Lauritsen, M. A., Jones, P. J., Merrill, I. M., and Wintrobe, M. M., The anemia of infection. I. Hypoferremia, hypercupremia, and alterations in porphyrin metabolism in patients. J. Clin. Invest., 1946, 25, 65.

32. Cartwright, G. E., Lauritsen, M. A., Humphreys, S., Jones, P. J., Merrill, I. M., and Wintrobe, M. M., The anemia of infection. II. The experimental production of hypoferremia and anemia in dogs. J. Clin. Invest., 1946, 25, 81.

33. Buchwald, K. W., and Hudson, L., The distribution of iron and copper in malignant neoplastic disease. Cancer Research, 1944, 4, 645.
34. Schotten, W., Zum eisengehalt verschiedener krebsgewebe. Arch. Geschwultstforsch, 1951, 3, 123.

35. Cartwright, G. E., Gubler, C. J., and Wintrobe, M. M., The anemia of infection. XII. The effect of turpentine and colloidal thorium dioxide on the plasma iron and plasma copper of dogs. J. Biol. Chem., 1950, 184, 579.

36. Freireich, E. J., Miller, A., Emerson, C. P., and Ross, J. F., The effect of inflammation on the utilization of erythrocyte and transferrin iron for hemoglobin synthesis. J. Clin. Invest., 1955, 34, 934.

37. Wasserman, L. R., Rashkoff, I. A., Leavitt, D., Mayer, J., and Port, S., The rate of removal of radioactive iron from the plasma-an index of erythropoiesis. J. Clin. Invest., 1952, 31, 32.

38. Peterson, R. E., Plasma radioactive iron turnover in acute viral hepatitis. Proc. Soc. Exper. Biol. \& Med., 1953, 84, 47.

39. Finch, S. C., and Finch, C. A., Idiopathic hemochromatosis, an iron storage disease. A. Iron metabolism in hemochromatosis. Medicine, 1955, 34, 381.

40. Elmlinger, P. J., Huff, R. L., Tobias, C. A., and Lawrence, J. H., Iron turnover abnormalities in patients having anemia: Serial blood and in vivo tissue studies with $\mathrm{Fe}^{59}$. Acta haemat., 1953, 9, 73.

41. Crosby, W. H., and Akeroyd, J. H., The limit of hemoglobin synthesis in hereditary hemolytic anemia ; its relation to the excretion of bile pigment. Am. J. Med., 1952, 13, 273. 